\title{
Lessons of the crisis for emerging markets
}

\author{
Barry Eichengreen
}

Published online: 17 March 2010

(C) Springer-Verlag 2010

\begin{abstract}
This paper analyzes the impact of the global financial crisis on emerging markets. It argues that the crisis will have enduring implications for policy toward the development and liberalization of financial markets. In particular, emerging markets will rely (even) less on external finance and adopt a less permissive approach to foreign bank presence. In contrast, the crisis will have a much more limited impact on other aspects of globalization. More controversially, the paper argues that the crisis is unlikely to have a major impact on the structure of the international monetary system.
\end{abstract}

\section{Introduction}

Unlike other recent financial crises, the seeds of this one were sown in the United States. This crisis erupted in America in the summer of 2007 and the shock waves radiated out from there. The crisis was rooted first and foremost in lax regulation and skewed incentives in U.S. financial markets. ${ }^{1}$ But within a few months it had engulfed the entire world. It thus has important implications for high-, medium- and low-income countries alike.

In this paper I focus on the lessons for middle-income countries, what are popularly called emerging markets. Given the origins of the crisis a large literature has already developed around the lessons for the advanced countries. ${ }^{2}$ And

\footnotetext{
${ }^{1}$ There is a view that the crisis was due principally to large capital flows into the United States, which lowered lending standards and fueled credit market excesses, and that these large capital inflows reflected the excess of saving over investment in Emerging Asia and the oil-exporting economies. My own view, expressed elsewhere, is that this problem of global imbalances, while adding fuel to the fire, was not the spark. And as for the origin of the imbalances, it takes two to tango; the inadequacy of saving relative to investment in the United States was equally part of the story.

${ }^{2}$ My own take is Eichengreen (2009a).

B. Eichengreen $(\triangle)$

Department of Economics, University of California, Berkeley, 508-1 Evans Hall, MC \#3880,

Berkeley, CA 94720-3880, USA

e-mail: eichengr@econ.berkeley.edu
} 
organizations from the International Monetary Fund to the United Nations and the Overseas Development Institute have focused on the plight of the poor countries. ${ }^{3}$ The implications for middle-income countries have received less attention for reasons that are not entirely obvious. For a time there was the belief that emerging markets might decouple from the advanced countries and consequently that the crisis had no first-order repercussions for them. While decoupling proved to be a mirage, important emerging markets, starting with China, have bounced back smartly from disruptions to their exports and growth. Again this may have created a subconscious tendency to minimize the implications.

The lessons for the United States and the other high-income economies are clear. They need to strengthen supervision and regulation and address agency problems in their financial markets. They need to finish repairing their broken financial systems. When growth resumes they will have to address their gaping budget deficits and rising debts. For low-income countries the implications are also clear. They need to continue investing in education, health care and other basic human services and building the physical and organizational infrastructure needed to penetrate foreign markets. There may be no question of the desirability of more help from outside, but they must be prepared to do these things on their own insofar as the more slowly growing advanced countries may now be less forthcoming with aid.

But what about emerging markets? More than the fact that the impact on their economies has been relatively muted, there is a lack of clarity about the policy lessons. How, in light of recent events, should emerging markets modify their terms of engagement with global trade and finance? What are the implications for supervision and regulation of their financial systems, given that supervision and regulation in the high-income countries, traditionally regarded as role models in international standard setting, have been revealed as deficient? Should monetary, fiscal and exchange-rate policies be rethought in light of new evidence on what has and has not worked? Now that recent events have given emerging markets more influence over reform of the international financial architecture, for what specific changes should they push?

The crisis also reminds us that it is appropriate for pundits from "advanced" countries to show modesty and restraint when sketching lessons for emerging markets. But I won't let that stop me.

\section{Assumptions}

Anyone seeking to draw lessons must immediately confront the question: are the structural consequences of the crisis permanent or transitory? Will large capital flows resume, or will countries have significantly greater difficulty in accessing foreign finance? Will the financial sector no longer be a turbocharged engine of growth in the U.S., UK and other advanced countries? Will there be a permanent rise in U.S. savings and fall in Chinese savings, or will global imbalances return? Will countries that have held down currencies and domestic demand in pursuit of export-led growth now modify their strategies? Will trade grow more slowly? Will other aspects of globalization be rolled back? Or will this too pass? Will the new normal in fact resemble the old normal?

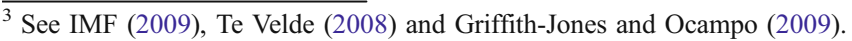


For purposes of analysis I assume the following. The globalization of finance will be partly rolled back, or at least capital flows will grow less rapidly. The crisis is a reminder of the risks when the domains of financial business and of supervision and regulation do not coincide - when banks and markets are global but regulation is local. National oversight then creates scope for regulatory arbitrage. No one national regulator will have the information and powers needed to avert and resolve problems of financial instability. One can imagine a global regulator, but governments remain unwilling to cede this authority to a supranational body. And loosely organized committees and colleges of regulators, no matter how frequently they meet, are unlikely to constitute a fully-adequate substitute. Unable to expand the domain of regulation beyond national borders, there will consequently be a tendency for governments to roll back the domain of financial business to coincide with the scope of oversight. The cross-border operations of banks and other financial institutions will be more tightly limited. More stringent capital and liquidity requirements for bank and nonbank financial institutions will make intermediation more costly and cause lending, both domestic and international, to grow more slowly. Forcing trading in derivatives into clearinghouses and onto exchanges will limit instrument diversity and make hedging foreign exposures more costly. This is not to imply that capital flows will evaporate, but assuming that the experience of the crisis is not forgotten they are likely to grow more slowly. [Table 1 shows the most recent Institute of International Finance estimates and forecast at the time of writing.]

In contrast, the globalization of trade and production will not be rolled back. The logic of global supply chains, production networks, and outsourcing remains compelling. The growth of trade in parts and components in East Asia reflects advances in transport technology-containerization-and what we have learned

Table 1 Emerging market economies: external financing (in billions of U.S. dollars)

\begin{tabular}{lrrrr}
\hline & \multicolumn{1}{c}{2007} & 2008 & $2009 \mathrm{f}$ & $2010 \mathrm{f}$ \\
\hline Private inflows, net & 1252.2 & 649.1 & 348.6 & 671.8 \\
Equity investment, net & 601.9 & 430.8 & 425.1 & 533.5 \\
Direct investment, net & 499.8 & 512.5 & 343.0 & 459.4 \\
Portfolio investment, net & 102.1 & -81.7 & 82.2 & 74.1 \\
Private creditors, net & 650.2 & 218.3 & -76.5 & 138.2 \\
Commercial banks, net & 431.4 & 102.7 & -82.7 & 48.5 \\
Nonbanks, net & 218.8 & 115.6 & 6.2 & 89.7 \\
Official inflows, net & 42.9 & 55.5 & 63.6 & 43.4 \\
IFIs & 4.1 & 26.6 & 43.7 & 26.2 \\
Bilateral creditors & 38.8 & 28.9 & 19.9 & 17.2 \\
Equity investment abroad, by residents, net & -285.1 & -221.9 & -139.3 & -226.0 \\
Resident lending/other, net & -482.6 & -555.0 & -118.1 & -271.2 \\
\hline
\end{tabular}

Institute of International Finance, "Capital Flows to Emerging Market Economies” (3 October 2009), www.iif.com 
about containerization is not about to be forgotten. ${ }^{4}$ The outsourcing of call centers and back office services to India reflects the growth of global broadband and satellite communication, whose advantages the crisis has done nothing to diminish. To be sure, trade requires trade credit and the crisis severely disrupted access to such credit, for small firms in particular. But this disruption proved temporary, and credits fully collateralized by trade deliverables are the form of capital least likely to be diminished in availability as a result of the crisis. ${ }^{5}$

If trade grows more slowly, this will reflect protectionist pressures bequeathed by the crisis. High unemployment fuels protectionist sentiment. Governments are loath to see the benefits of expensive fiscal stimulus leak out to free riders in the form of increased domestic spending on foreign goods. Similarly, now that governments have larger stakes in domestic auto companies, they may become less committed to the maintenance of a level playing field for foreign motor-vehicle producers. Murky protectionism there has been. At the same time, the fact that a wide range of countries have proceeded with fiscal stimulus diminishes the free-rider problem. The problem of high unemployment will pass. Governments remain committed to completing the Doha Round.

Similarly, global migration will not be rolled back. Cross-border migration has grown rapidly in recent years, reflecting the strong growth of the global economy but also the aforementioned advances in transportation and communication. ${ }^{6}$ (See Table 2.) The increase in information about living standards and job opportunities in high-income countries that has flowed to low-income regions through everything from earlier migrants to soap operas will not now evaporate. Neither will the transport and logistical support for future migration provided by past migration. Demographic imbalances between parts of the high- and low-income world will continue to provide a logic for large-scale migration. Again, the kicker is whether tougher economic times in the high-income countries will precipitate a backlash against foreign workers. While there is some evidence of this in Europe, it is striking that, so far at least, the crisis has provoked little hostility toward foreign workers in the United States. ${ }^{7}$

Neither the U.S. nor China-or for that matter any other major economy-will abandon its tried-and-true growth model. To be sure, a situation where the United States runs a current account deficit of $7 \%$ of GDP and absorbs $75 \%$ of the collective current account surpluses of the rest of the world is unlikely to recur. There are a number of reasons for thinking that the increase in household savings in the United States will be long lasting. ${ }^{8}$ With U.S. demand growing more slowly, the Chinese authorities will continue to boost domestic demand. The ageing of China's population will reinforce the trend toward lower savings rates. More U.S. and less Chinese production of traded goods necessarily implies an adjustment in the real

\footnotetext{
${ }^{4}$ Another illustration is advances in air freight that encourage the export of cut flowers from Latin America or of Maine lobsters to Japan.

${ }^{5}$ In addition, the official community has stepped in with a range of initiatives to maintain the supply of trade credit.

${ }^{6}$ See International Organization for Migration (2008).

${ }^{7}$ Thus, while the crisis occupied center stage in the 2008 presidential election, the issue of undocumented immigration largely fell off of the electorate's radar screen.

${ }^{8}$ See Carroll and Slacelek (2009) for a careful analysis.
} 
Table 2 Regional distribution of international migrants, 1960-2010

\begin{tabular}{|c|c|c|c|c|c|c|}
\hline & \multicolumn{3}{|l|}{1960} & \multicolumn{3}{|l|}{2010} \\
\hline & $\begin{array}{l}\text { Total } \\
\text { migrants } \\
\text { (millions) }\end{array}$ & $\begin{array}{l}\text { Share of } \\
\text { world } \\
\text { migrants } \\
\text { (percent) }\end{array}$ & $\begin{array}{l}\text { Share of } \\
\text { population } \\
\text { (percent) }\end{array}$ & $\begin{array}{l}\text { Total } \\
\text { migrants } \\
\text { (millions) }\end{array}$ & $\begin{array}{l}\text { Share of } \\
\text { world } \\
\text { migrants } \\
\text { (percent) }\end{array}$ & $\begin{array}{l}\text { Share of } \\
\text { population } \\
\text { (percent) }\end{array}$ \\
\hline \multicolumn{7}{|l|}{ World } \\
\hline $\begin{array}{l}\text { (excluding former } \\
\text { Soviet Union and } \\
\text { former Czechoslovakia) }\end{array}$ & 74.1 & & 2.7 & 188.0 & & $2.8 \%$ \\
\hline \multicolumn{7}{|l|}{ By Region } \\
\hline Africa & 9.2 & 12.4 & 3.2 & 19.3 & 10.2 & 1.9 \\
\hline Northern America & 13.6 & 18.4 & 6.7 & 50 & 26.6 & 14.2 \\
\hline Latin American \& Caribbean & 6.2 & 8.3 & 2.8 & 7.5 & 4.0 & 1.3 \\
\hline Asia & 28.5 & 38.4 & 1.7 & 55.6 & 29.6 & 1.4 \\
\hline GCC states & 0.2 & 0.3 & 4.6 & 15.1 & 8.0 & 38.6 \\
\hline Europe & 14.5 & 19.6 & 3.5 & 49.6 & 26.4 & 9.7 \\
\hline Oceania & 2.1 & 2.9 & 13.5 & 6.0 & 3.2 & 16.8 \\
\hline \multicolumn{7}{|l|}{ By Human Development Category } \\
\hline Very high HDI & 31.1 & 41.9 & 4.6 & 119.9 & 63.8 & 12.1 \\
\hline OECD & 27.4 & 37.0 & 4.2 & 104.6 & 55.6 & 10.9 \\
\hline High HDI & 10.6 & 14.2 & 3.2 & 23.2 & 12.3 & 3.0 \\
\hline Medium HDI & 28.2 & 38.1 & 1.7 & 35.9 & 19.1 & 0.8 \\
\hline Low HDI & 4.3 & 5.8 & 3.8 & 8.8 & 4.7 & 2.1 \\
\hline
\end{tabular}

United Nations Human Development Report (2009)

exchange rate between the two countries. But these developments are likely to be more gradual than abrupt.

Finally, I assume that this was not the last global financial crisis that we will experience in our lifetimes.

\section{Implications for trade and financial policies}

A first policy lesson is that a strategy of export-led growth entails greater risks than appreciated previously. The point is not just that global demand is volatile; it is that trade appears to be more elastic with respect to the cycle and more vulnerable in downturns than thought previously. The decline of exports in emerging Asia in late 2008 and early 2009 was nothing short of catastrophic, with volumes down by as much as $40 \%$ year on year. The consequences for GDP were dramatic. In Singapore, an extreme case, GDP fell at an annual rate of $13 \%$ in the first quarter of $2009 .{ }^{9}$ Unbalanced growth emphasizing exports, just like excessive dependence on foreign finance, creates vulnerabilities. Evidently, trade as well as finance can exhibit sudden stops.

\footnotetext{
${ }^{9}$ This according to the July 2009 revision of figures for 2009 Q1. GDP in 2009 Q1 was down $10 \%$ of GDP in 2008 Q1.
} 
The destabilizing macroeconomic impact is even greater to the extent that a growing share of investment in emerging markets is export linked. In China, investment in gross fixed capital in the tradable sectors increased from $28 \%$ of total investment in the first half of the 1990s to $36 \%$ per cent in 2003-2007. In Brazil the comparable increase was from 19 to $56 \%{ }^{10}$ Falling export demand therefore means falling domestic demand at the same time. ${ }^{11}$ Some shift from the excessive inward orientation of investment in countries like Brazil was clearly desirable. The question is whether, given what we have now learned about the volatility of export demand, the shift has gone too far.

Determining the appropriate policy response requires first identifying the causes of the recent collapse of trade. It could be that the collapse reflected despair about future demand leading to an exceptional drawdown of inventories for traded goods. With evidence now that governments are prepared to intervene to stabilize demand, equally violent inventory corrections may be unlikely. It could be that trade was hammered by disruptions to the supply of trade credit. To the extent that this is the explanation, then enhancing the public provision of emergency trade finance is an alternative to altering the composition of production and investment. Or it could be that production fragmentation and the elaboration of global supply chains, for the manufactured products in which emerging Asia specializes in particular, have somehow increased the sensitivity of trade with respect to the cycle, in which case more far-reaching policy adjustments may be called for. ${ }^{12}$

Second, the crisis serves as a reminder, if one was needed, of the risks of excessive dependence on foreign finance. Countries with large current account deficits and substantial external financing requirements were disproportionately hit by the crisis as foreign investors deleveraged and capital flows dried up. Emerging Asian and Latin American countries have managed their current accounts and external financing requirements more carefully in light of prior experience. But the same cannot be said of Central and Eastern Europe. (See Table 3.) With benefit of hindsight it is hard to conceive how the Latvian authorities, to take the most glaring example, could have permitted the country's current account deficit to soar to some $25 \%$ of GDP. It, as well as other countries in a less extreme version of this same position, saw domestic demand compressed violently when foreign finance for their deficits dried up. At the time of writing, Latvian GDP is estimated to have contracted by an astonishing $18 \%$ in 2009 - this despite a rescue package jointly financed by the IMF and EU equivalent to $34 \%$ of national income.

East Asia and Latin America may have avoided large current account deficits but they did not avoid currency and maturity mismatches. South Korea's problem was essentially a maturity mismatch: banks that lent long-term to shipbuilders who had receivables in dollars (which would accrue when the boats were floated) squared their currency books by borrowing short, offshore, in dollars. When the crisis hit, their short-term dollar funding dried up, setting off alarms. In Mexico and Brazil, in contrast, the problem was essentially a currency mismatch. While on-balance sheet

\footnotetext{
${ }^{10}$ Bank for International Settlements (2009), p.75.

${ }^{11}$ Absent offsetting government action-see below.

12 That Latin American trade, which is more heavily in raw materials, held up better in the crisis is consistent with the notion that recent sensitivity is somehow connected to production fragmentation and global supply chains, but this observation still does not identify the mechanism.
} 
Table 3 Summary of balances on current account (billions of U.S. dollars)

\begin{tabular}{|c|c|c|c|c|c|}
\hline & 2006 & 2007 & 2008 & 2009 & 2010 \\
\hline Advanced economies & -458.9 & -365.3 & -533.1 & -261.7 & -166.2 \\
\hline United States & -803.5 & -726.6 & -706.1 & -369.8 & -324.7 \\
\hline Euro $\operatorname{area}^{\mathrm{a}}$ & 41.0 & 34.4 & -92.7 & -82.1 & -36.4 \\
\hline Japan & 170.4 & 211.0 & 157.1 & 96.9 & 105.6 \\
\hline Other advanced economies ${ }^{\mathrm{b}}$ & 133.3 & 116.0 & 108.5 & 93.3 & 89.3 \\
\hline \multicolumn{6}{|l|}{ Memorandum } \\
\hline Newly industrialized Asian economies & 90.0 & 103.6 & 76.1 & 98.0 & 96.0 \\
\hline Emerging and developing economies & 659.7 & 664.5 & 724.6 & 355.6 & 548.1 \\
\hline \multicolumn{6}{|l|}{ Regional groups } \\
\hline Africa & 52.4 & 31.7 & 32.4 & -37.1 & -22.3 \\
\hline Central \& eastern Europe & -87.3 & -130.8 & -155.2 & -48.4 & -62.5 \\
\hline Commonwealth of Independent States ${ }^{c}$ & 96.3 & 71.7 & 108.1 & 48.0 & 79.6 \\
\hline Developing Asia & 288.0 & 413.8 & 423.9 & 381.5 & 438.6 \\
\hline Middle East & 262.6 & 264.9 & 345.3 & 42.8 & 151.6 \\
\hline Western hemisphere & 47.8 & 13.1 & -29.9 & -31.3 & -36.8 \\
\hline
\end{tabular}

${ }^{a}$ Reflects errors, omissions, and asymmetries in balance of payments statistics on current account, as well as the exclusion of data for international organizations and a limited number of countries. Calculated as the sum of the balance of individual euro area countries

b In this table, "other advanced economies" means advanced economies excluding the United States, euro area countries, and Japan

${ }^{\mathrm{c}}$ Georgia and Mongolia, which are not members of the Commonwealth of Independent States, are included in this group for reasons of geography and similarities in economic structure

IMF World Economic Outlook (October 2009)

foreign currency mismatches had been reduced, corporations in both countries had increased their off-balance sheet foreign currency exposure through derivative positions. These corporations bet against depreciation of the local currency by selling foreign exchange options in the offshore market and were smashed when those currencies depreciated by more than $30 \%$ following the failure of Lehman Brothers. ${ }^{13}$ These are arguments for why regulators should require banks to more closely match the maturity of their assets and liabilities when operating in foreign currency and why they should regulate firms' positions in forward and options markets.

The crisis also sheds new light on earlier arguments about foreign bank presence. Contrary to worries that foreign banks would cut and run at the first sign of trouble, foreign banks maintained support for their subsidiaries in emerging markets to a remarkable degree. ${ }^{14}$ Cross-border lending fell by less in countries with significant foreign bank presence than in emerging markets where foreign bank ownership was not dominant, other things equal. If anything, domestic banks with shallower pockets

\footnotetext{
${ }^{13}$ See Jara et al. (2009).

${ }^{14}$ Bank for International Settlements (2009), p.83.
} 
were more likely to cut back in the crisis. ${ }^{15}$ Here is one place where Asian countries that have been reluctant to open to foreign banks might take a cue from Central and Eastern Europe. Of course, whether home countries will now be as permissive in encouraging banks' foreign operations, given the difficulties of multinational supervision, remains to be seen.

Other positive aspects notwithstanding, foreign bank presence was also associated with currency mismatches. In Central and Eastern Europe foreign banks were the vehicles for extending euro- and Swiss franc-denominated corporate, home and car loans to firms and households with incomes in local currency-something that added to corporate and household financial distress when local currencies depreciated. Austrian, Italian and Swiss regulators, seeing their banks with assets and liabilities both in their own currencies, happily looked the other way. The implication is that emerging markets, while encouraging foreign bank entry, should at the same time strictly regulate local lending practices.

These banking-sector controversies bring us back to the argument for local bond markets. Bond markets provide an alternative to bank intermediation. There is evidence that countries with better developed bond markets experienced less negative fallout from the crisis as large firms in particular retained access to nonbank sources of finance. ${ }^{16}$ Opening those markets to foreign investors, on the other hand, appears to have been a mixed blessing. South Korea, the East Asian country with the largest share of its security market capitalization held by foreign investors, also experienced the sharpest price and exchange rate corrections as those foreign investors, forced to deleverage, desperately repatriated their funds. Encouraging foreign investor participation is a quick way of jump-starting local bond market activity. But recent experience suggests that quickest is not necessarily best.

\section{Implications for monetary, fiscal and exchange rate policies}

The crisis also underscores the advantages of policy space. Stronger budget balances and lower debt ratios gave emerging markets more room for countercyclical fiscal policies. Discretionary fiscal stimulus of $2.9 \%$ of GDP in China, $2.0 \%$ in Russia and $1.5 \%$ in Mexico (all averages for 2009-10) has helped to buffer the effects of falling export demand, an experience that stands in sharp contrast to earlier crises. ${ }^{17}$ There has also been room for automatic stabilizers; budget deficits associated mainly with more slowly growing tax revenues amount to some 3\% of GDP in 2009 in G20 emerging markets. Again it would not have been possible to allow for this stabilizing impact had fiscal positions not been strong on the eve of the crisis. Finally it has been possible to expand social programs this time to help shelter society's most

\footnotetext{
15 That said, they appear to have cut back less than in earlier crises, reflecting greater capitalization, fewer nonperforming loans and higher profitability on the eve of the event.

${ }^{16}$ Or at least had been able to finance their operations at longer tenors, obviating the need to go back to the markets once conditions deteriorated. Bank for International Settlements (2009), p.84.

${ }^{17}$ It can be argued that China is in fact doing more than this insofar as the authorities also directed the banks to increase their lending for infrastructure and other fixed-investment projects in the first half of 2009.
} 
vulnerable members from the blow of the crisis as a result of the relatively strong stance of fiscal policy going in. All this is a reminder of the value of keeping one's powder dry.

Economists will forever debate the merits of IMF advice to jack up interest rates in 1997-8, but given how the interaction of foreign currency obligations with sharp currency depreciation could cause an outright financial meltdown it is hard to see what else the countries concerned could have done. ${ }^{18}$ In 2008-9, in contrast, lower inflation, greater central bank credibility and less foreign currency debt facilitated the more active use of monetary policy. Essentially all G20 emerging markets in Asia and Latin America had room to cut policy rates. China, India, Korea and Turkey all cut theirs by more than 2 percentage points in the 6 months from August 2008. The reduction in policy rates was even more dramatic, if starting from higher levels, in Colombia and Brazil. Some might argue that the different response this time reflected differences in the nature of the crisis or better economic advice. But given how emerging markets with less policy credibility and more foreign debts (Pakistan, Jamaica, much of Eastern Europe) were forced to raise rates, it seems clear that the stronger position entering the crisis is the main explanation for the different response.

This more flexible use of monetary policy has been facilitated by the shift from exchange rate targeting to inflation targeting in Latin America and, to a lesser extent, East Asia. During the period when external demand was strong, countries were in a position to allow their currencies to strengthen to prevent overheating. Then could then allow their exchange rates to adjust downward when the crisis struck and external demand slackened. ${ }^{19}$ Currency depreciation when the economic backdrop deteriorates is not entirely welcome - it is a symptom of the fact that all is not wellbut it helped to maintain export competitiveness at the time when exports were needed most. Brazil, Chile, Colombia and Mexico all allowed felt benefits from this. Asian countries, as is their wont, were more reluctant to allow their currencies to fluctuate, although there were sharp declines in the Korean won and Indonesian rupiah. The existence of coherent inflation targeting regimes in all these countries allowed exchange rates to adjust without expectations becoming unanchored. In some cases, there was the feeling that fluctuations were excessive, leading the authorities to intervene in the foreign exchange market. This is a reminder that even a well-developed commitment to inflation targeting does not entirely allow for neglect of exchange rate fluctuations.

In the longer run, this episode of heightened currency volatility will undoubtedly encourage more discussion of collective currency pegs, common currency baskets, and regional monetary unions. These topics are hardy perennials, and recent events will do nothing to make them go away-nor bring discussions to an early conclusion. The more immediate policy question is how to modify the conduct of inflation targeting. Recent events suggest that the standard inflation targeting framework where the monetary policy instrument is adjusted in response to deviations of expected future inflation and the output gap from their respective targets is seriously incomplete; it has to be augmented by attaching a weight to

\footnotetext{
${ }_{18}$ Other than slap on controls or repudiate their debts.

${ }^{19}$ Here the counterexample of the Baltics is informative.
} 
financial-stability concerns. Monetary policy makers cannot treat threats to financial stability with benign neglect or dismiss those threats as the responsibility of the regulators. But the question of how, exactly, to modify the conduct of monetary policy to incorporate those macro-prudential concerns remains unanswered. Until analysis of that question at least has more structure, central bankers will be flying by the seat of their pants.

\section{Implications for the international financial architecture}

Dissatisfaction in emerging markets with prevailing international monetary and financial arrangements is not new. Earlier instances where they were caught in the cross-winds were met mainly by steps to bullet-proof their economies, although there were also subsidiary efforts, mainly in Asia, to build regional supports. Insofar as the lessons of earlier crises motivated efforts to strengthen budgets, work down public debts, limit current account deficits and more carefully manage foreign currency exposures, the resulting reduction in vulnerabilities and increase in policy space have been profoundly advantageous, as documented above.

Whether the accumulation of foreign reserves, the other approach to bullet proofing, has been equally beneficial is less obvious. The one thing it has clearly been is expensive. In China reserves of more than $\$ 1,500$ per resident are the equivalent of $25 \%$ of per capita income. Devote those resources instead to physical investment where they would conservatively earn a rate of return of $8 \%$, and China accrues the equivalent of another two percentage points of economic growth. ${ }^{20} \mathrm{Or}$ devote those resources to consumption, and living standards are two per cent higher. In Korea, where reserves were the equivalent of $20 \%$ of per capita income on the eve of the crisis, the implications are analogous. The situation is again similar in a variety of other high-reserve countries.

The problem with the strategy, besides the fact that it is expensive, is that it is not clear that the reserves in question can be used. When Korea's reserves threatened to fall below $\$ 200$ billion, a very high threshold, the markets showed alarm and the authorities were unable to access them further. ${ }^{21}$ To obtain resources with which to replace the private-sector dollar liquidity that had dried up the Bank of Korea had to negotiate a $\$ 30$ billion swap facility with the Federal Reserve.

None of this is to deny the value of insurance, but it does point to the need for more cost-effective ways of obtaining it. Regional reserve pooling is one possibility. ASEAN +3 continues to elaborate the Chiang Mai Initiative, in the spring of 2009 taking another step toward its multilateralization and agreeing to the creation of a regional surveillance unit. But there has been reluctance on the part of the participants to activate their arrangement; if they were unwilling to do so in the wake of Lehman Brothers' bankruptcy it is hard to imagine circumstances under

\footnotetext{
${ }^{20}$ One can argue that one should apply such calculations only to a fraction of China's total reserves, bringing down the sacrifice in income. On the other hand one can argue that the rate of return to physical capital is higher than $8 \%$.

${ }^{21} \$ 200$ billion was the ballpark for the country's external financing requirement over the next 9 months on the assumption, hardly realistic, that none of its short-term external debt or maturing long-term external debt was renewed (Huang 2008).
} 
which they will. The core problems are conditionality and repayment: countries are reluctant to lend reserves without assurance that they will be paid back, and repayment can be confidently expected only when loans come packaged with conditions. But sovereigns hesitate to demand conditions of their neighbors since doing so threatens to poison diplomatic relations. ${ }^{22}$ ASEAN +3 would address this dilemma by outsourcing the authority to determine conditionality and disburse funds to a board of experts independent of governments. ${ }^{23}$ So far, however, this remains a political bridge too far. And as long as Asian governments remain reluctant to cross it, their regional reserve pool will remain all horse and no saddle. ${ }^{24}$

In Latin America, where proto-reserve-pooling arrangements are at an even earlier stage, Colombia and Mexico have contracted for insurance with the IMF, qualifying for its new Short-Term Liquidity Facility. But the problem of stigma at the point of drawing evidently remains. When Mexico needed dollars late last fall it, like Korea, arranged a $\$ 30$ billion swap with the Federal Reserve. Evidently the Fed is the true reinsurer of last resort. ${ }^{25}$ That in times of crisis such countries are the mercy of the United States is explanation enough for their dissatisfaction with the prevailing architecture.

The obvious vehicle for efficient reserve pooling is the IMF. Insofar as balanceof-payments shocks are more highly correlated within than across regions, global reserve pooling has advantages over regional reserve pooling. And reserve pooling was in fact one of the original rationales for creating the Fund. Thus the reluctance of emerging markets to make freer use of the Fund is a serious inefficiency. The question is what can be done to mitigate the stigma associated with IMF programs. Knowing that they have more voice and influence in the institution may reassure emerging markets: hence the case for quota reform, for restructuring the executive board to reduce the overrepresentation of the G10, and for an open leadership selection process that might someday produce a managing director from an emerging-market country.

But it is not clear that incremental reforms will cause such countries to flock back to the IMF. ${ }^{26}$ Emerging markets need to specify exactly what changes in the structure of the institution they require in order to regard accessing its facilities as attractive. My own suggestion is not further steps to redress the political balance-

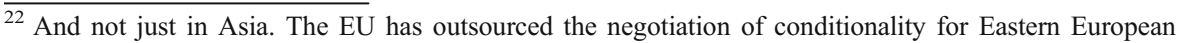
countries receiving joint assistance to the IMF.

${ }^{23}$ See Eichengreen (2009b). Unwilling to do so, ASEAN+3 instead outsources the responsibility to the IMF, which means in effect not outsourcing it at all.

${ }^{24}$ European experience is revealing in this regard. So long as the decision over lending and conditionality remained in the hands of national governments and central banks, there was a reluctance to provide extensive support. The creditor countries took steps to limit their obligations, notably in the case of Germany and the Emminger letter. Arguably, now that the decision to provide emergency credits has been outsourced to an independent entity, the European Central Bank, the response to crises has been faster and more forceful.

${ }^{25}$ As is the ECB in Europe. Since December China has also moved to provide renminbi swap facilities for a variety of trading partners. But since the renminbi is inconvertible, these swaps are mainly useful for importers who would otherwise find it difficult, given foreign exchange shortages, to settle their accounts with Chinese firms; renminbi credits cannot be easily used in other financial-market operations.

${ }^{26}$ Especially in Asia, where turning to the IMF is seen as political poison by any self-respecting government.
} 
since such steps haven't produced results when pursued at the regional level. ${ }^{27}$ Rather, it is to remove politics from the Fund's short-term decision making by strengthening the independence of the management team and empowering it to make key operational decisions. The IMF could then provide emergency liquidity quickly, as did the Federal Reserve in November 2008, but without the sour taste of politics. Officials from emerging markets may not like this idea, but then they are obliged to specify what alternative reforms would render the IMF attractive for pooling their reserves.

Finally there is what emerging markets should see as the priorities for reforming the international monetary system in light of the crisis. Recent events have pointed up the problems with a dollar-based reserve system. Here officials from emerging markets have become more vocal, but they have yet to adequately specify their objectives. Thus while both China and Russia have been campaigning for an enhanced role for the SDR, they have also been taking steps to encourage the expanded use of their national currencies in their countries' own cross-border transactions, with their immediate neighbors in particular. Absent a more coherent message, there will not be coherent reform.

This flurry of initiatives is open to alternative interpretations. ${ }^{28}$ Mine is that China's long-run objective is to enhance the renminbi's own international-currency role, initially as a regional reserve currency and ultimately as a global reserve currency. (Russia and Brazil have similarly made noises about enhancing the use of their currencies in their respective parts of the world.) This is the best way of understanding recent initiatives designed to encourage firms in China's southern provinces to settle more cross-border transactions in renminbi as well as the renminbi swap arrangements that the country has negotiated with various trading partners. Of course, making the renminbi an attractive form in which to hold reserves will require not just that more of China's trade be invoiced and settled in its own currency but also that it develop deep and liquid markets in renminbi-denominated securities and that that the currency become convertible on capital account. China has a plan for elevating Shanghai to the status of a major international financial center by 2020. Financial-center status similarly entailing capital-account convertibility, this suggests the relevant time frame for the associated steps.

To be sure, the U.S. (and the euro area) will not have gone away. This points to the development of a multi-currency reserve system not unlike that which prevailed in the first era of globalization prior to 1914. With multiple countries possessing deep and liquid financial markets open to foreign investors, there will be multiple forms and places in which to hold reserves. In this multipolar world, not unlike the multipolar world that existed before 1914, no single issuer will monopolize the

\footnotetext{
${ }^{27}$ Thus, the Chiang Mai Initiative Multilateralization involved a formula for the voting shares of China, Japan, Korea and the ASEAN countries that has not obviously made activation of that arrangement more likely.

${ }^{28}$ For example, the SDR initiative could simply be addressed at domestic constituencies which are not pleased that so much of the national patrimony is invested in U.S. dollars; the SDR proposal is thus a way for the People's Bank of China to signal its constituents that it is aware of its fiduciary responsibility. Or it could simply be a way for emerging markets to signal the G20 that they want to be taken seriously in discussions of international monetary reform.
} 
privilege of supplying the reserve unit. ${ }^{29}$ And the fact that there will exist more than one country with deep and liquid markets in a position to supply reserves will be a constructive source of discipline on policy.

Where does this leave the SDR and other more radical visions for international monetary reform-more regional monetary unions for example? China being aware that the longer it waits the more likely its economy and currency will dominate East Asia, is unlikely to evince much enthusiasm for pooling its monetary sovereignty. And if China is serious about the renminbi as a reserve currency, then surely it can't be serious about the SDR as well. My suspicion is that talk of an expanded role for the SDR is a way for China and other emerging market to signal their concern that they might suffer losses on their existing dollar holdings. They would like to see a Substitution Account-like facility through which they could exchange some of their dollars for SDR-denominated claims on the margin. Alternatively they would like to see the United States offer a guarantee against losses on their existing dollar holdings. To the extent that their cooperation is needed on other aspects of the global agenda (agreement on reduced carbon emissions, for example), one can imagine the outlines of a bargain. But it is implausible that the international community would agree to relieve China of the entirety of its $\$ 1$ trillion-plus dollar reserve portfolio, much less that the U.S. would relieve emerging markets as a group of their dollar reserves. And it is even more implausible that the SDR could supplant national currencies as the main form of international reserves in our lifetimes. ${ }^{30}$

\section{Conclusion}

When I am told that the crisis will mark a fundamental break in the structure and management of the world economy, I am reminded of Hurricane Katrina. By laying bare the extent of American inequality, and also by the inadequacy of the publicsector response, Katrina, it was said, would mark a fundamental break in social policy and the role of government in the United States. But it was not too long before America slid back into its comfortable old ways. Analogously, there is now the question of whether once the crisis passes business as usual will resume.

My suspicion, noted at the outset of the paper, is that there will be no return to business as usual when it comes to the regulation of finance. The demand for more stringent financial regulation will be enduring. Leverage, cross-border portfolio investment, and transactions in complex derivative securities will be rolled back or at least grow more slowly than in the recent past. Consequently emerging markets (recently, limited mainly to Central and Eastern Europe) that have relied heavily on foreign capital will have to finance more of their development at home. As the domain of bank operations is reorganized to coincide with the domain of regulation, emerging markets will be less able to outsource intermediation to foreign banks. Countries like South Korea and China that sought to harness finance as a growth

\footnotetext{
${ }^{29}$ Thus, I am pushing back against the argument that increasing returns owing to network externalities are so strong that there is only room in the market for a single dominant international currency.

${ }^{30}$ I develop the argument why in Eichengreen (2009c).
} 
engine, turning themselves into financial hubs for Northeast Asia, will have to look to other sectors.

By comparison, the crisis will have a much more limited impact on other dimensions of globalization. The fundamental social and technological factors supporting the rapid globalization of production and trade in recent years remain firmly in place. Emerging markets need to continue adapting their policies to take advantage of this "real existing globalization." This means making their economies more attractive for foreign investment by streamlining bureaucracy and imparting labor skills. It means continuing to run sound and stable monetary, fiscal and debtmanagement policies in good times so that they have space to deploy those policies in bad times.

More controversially perhaps, I have also argued that the crisis is unlikely to occasion fundamental changes in the structure of the international monetary system - in either exchange rate arrangements or the composition of reserves. To be sure, the system will continue to evolve. The dollar will become less dominant in the international monetary system for all the same reasons that the United States will become less dominant in the international economy. But, barring even more serious crises, this evolution will remain gradual, as has typically been the case in the past. Thus, the policy problem for emerging markets is to deal with the international monetary system that actually exists, not the one they imagine might exist.

Acknowledgement This is a revision of ADBI Working Paper no. 179. Financial support from the ADBI is gratefully acknowledged.

\section{References}

Bank for International Settlements (2009) Annual report. BIS, Basel

Carroll C, Slacelek J (2009) The American consumer: reforming, or just resting? unpublished manuscript, Johns Hopkins University

Eichengreen B (2009a) Strengthening the financial architecture: unanswered questions, paper for the Dubai Economic Council Annual International Conference (October)

Eichengreen B (2009b) Can Asia free itself from the IMF? Project Syndicate (June), www.project syndicate.com

Eichengreen B (2009c) The dollar's dilemmas, Foreign Affairs (July/August)

Griffith-Jones S, Ocampo J-A (2009) The financial crisis and its impact on developing countries, working paper no.53, Brasilia: UNDP (April)

Huang Y (2008) Measuring asia's external vulnerability, Citigroup Global Markets (8 October)

International Monetary Fund (2009) Implications of the global financial crisis for low-income countries. IMF, Washington, D.C

International Organization for Migration (2008) World migration report 2008. International Organization for Migration, Geneva

Jara A, Moreno R, Tovar C (2009) The global crisis and Latin America: financial impact and policy responses. BIS Q Rev (June), pp 53-68

Te Velde DW (2008) The global financial crisis and developing countries, background note. Overseas Development Institute, London 